\title{
PENGEMBANGAN USAHA KERBAU RAWA \\ DENGAN MODEL DESA SENTRA PEMBIBITAN (VILLAGE BREEDING CENTRE) DI KALIMANTAN SELATAN
}

\author{
Ahmad Suhaimi, Azwar Saihani, Rum Van Royensyah, dan Mahdiannor \\ Sekolah Tinggi Ilmu Pertanian (STIPER) Amuntai \\ E-mail : ahmad99ec@gmail.com
}

\begin{abstract}
ABSTRAK
Desa Sapala didominasi oleh agroekosistem lahan rawa lebak yang sangat potensial untuk peternakan kerbau rawa, merupakan usaha utama masyarakat sehingga sangat berperan menggerakkan perkekonomian desa. Tujuan pelaksanaan kegiatan Program Pengembangan Desa Mitra ini adalah mengembangkan kelembagaan pembibitan ternak pada peternakan rakyat, tercapainya perbaikan mutu genetik bibit memenuhi standar nasional, harga bibit yang bersaing, pengembangan ternak unggulan daerah, dan sebagai zona penyangga (buffer zone). Metoda yang digunakan adalah Partisipatory Rural Appraisal (PRA) bertujuan untuk mempelajari desa secara patisipatif, dan pelaksanaan Village Breeding Centre (VBC) bertujuan untuk meningkatkan kapasitas kelompok ternak kerbau rawa. Hasil luaran utama yang dicapai pelaksanaan program ini adalah : sentra produksi bibit kerbau rawa meliputi (berkembangnya kelembagaan pembibitan ternak pada peternakan rakyat, tercapainya perbaikan mutu genetik bibit memenuhi standar nasional, harga bibit yang bersaing, pengembangan ternak unggulan daerah). Hasil lain adalah sebagai zona penyangga (buffer zone).
\end{abstract}

Kata Kunci : Sentra Pembibitan, Kerbau Rawa, Agroekosistem

\section{PENDAHULUAN}

Desa Sapala didominasi oleh agroekosistem lahan rawa lebak, pengembangan kerbau rawa sudah cukup lama dilakukan di wilayah ini, selain itu lahan rawa berpotensi sebagai penyedia pakan hijauan yang palatable bagi kerbau. Berdasarkan potensi yang ada, pengembangan kerbau rawa mempunyai peluang besar dan prospek yang baik. Hal tersebut ditunjukkan dengan sumberdaya alam dan SDM seperti pengalaman beternak yang turun-temurun, dan hampir seluruh masyarakat mengusahakan ternak kerbau rawa (Suhaimi A, 2016).

Zona agroekologis desa Sapala di Kecamatan Paminggir Kabupaten Hulu Sungai Utara, dengan wilayah rawa sangat menguntungkan untuk budidaya kerbau rawa. Kerbau Rawa menduduki peran strategis sebagian besar masyarakat, tidak hanya sebagai penghasil daging, sumber pendapatan, daya tarik pariwisata.

Kerbau rawa sangat potensial sebagai penghasil daging, disamping mempunyai bobot badan realtif berat $( \pm$ 
500-600 kg) dan persentase karkasnya mencapai 50,26\% (Rohaeni et al., 2005). Menurut Toelihere (1979) dalam Siregar (2004), kerbau memiliki daya cerna terhadap serat kasar yang tinggi dan mampu memanfaatkan rumput berkualitas rendah, serta menghasilkan berat karkas yang relatif tinggi dibandingkan ternak sapi lokal.

Beternak kerbau mempunyai peran yang cukup penting terhadap perekonomian, karena merupakan usaha utama bagi masyarakat desa Sapala. Selain memberi manfaat ekonomi yang nyata, kepemilikan kerbau juga dapat dianggap sebagai lambang atau status sosial seseorang di masyarakat, semakin banyak kerbau yang dimiliki maka status pemiliknya semakin tinggi.

Tingkat produksi daging kerbau di Kalimantan Selatan sebesar 819.040 ton pada tahun 2004 menjadi 1.128.467 ton daging pada tahun 2009, namun empat tahun berjalan pada tahun 2013 terjadi penurunan produksi yang bermakna menjadi 824.781 ton atau sebesar $36,8 \%$ . Berdasarkan data BPS Kal-Sel (2014), ketersediaan dan kebutuhan konsumsi daging di Kalimantan Selatan masih mengalami kekurangan sebagai bahan pangan sumber protein.
Pihak lain, kondisi konsumsi daging masyarakat meningkat sebesar $4,7 \%$, yaitu 27.460 ton daging tahun 2006 menjadi 31.545 ton tahun 2010 (Dirjen Peternakan dan Kesehatan Hewan, 2010). Data indikator sosial ekonomi, kondisi ketersediaan dan kebutuhan daging di Kalimantan Selatan masih mengalami kekurangan sebagai pangan sumber protein (BPS Kal-Sel 2011).

Berdasarkan data di atas, kondisi ini menuntut usaha yang serius dari pemangku kepentingan untuk mengembangkan ternak kerbau guna mencukupi kebutuhan daging sebagai pangan sumber protein hewani. Peranan ternak kerbau rawa merupakan komoditas unggulan yang memiliki potensi untuk memasok kebutuhan daging sekaligus mendukung program swasembada daging nasional.

Kabupaten Hulu Sungai Utara (HSU) ditetapkan sebagai salah satu dari 7 kabupaten di Indonesia yang dijadikan daerah sumber bibit kerbau di Indonesia berdasarkan SK Menteri $\begin{array}{lll}\text { Pertanian } & \text { RI }\end{array}$ 2844/Kpts/LB.430/B/2012 tentang penetapan rumpun Kerbau Kalimantan Selatan (kerbau kalang) sebagai salah satu kerbau lokal dan kekayaan sumber 
daya genetik ternak lokal Indonesia yang harus dilindungi dan harus dilestarikan.

Pengembangan kerbau rawa diperlukan ketersediaan bibit yang berkelanjutan, namun berdasarkan analisis situasi, dan urgensi prioritas maka ditetapkan permasalahan meliputi : i) peternakan kerbau masih dilakukan secara tradisional, ii) pembibitan berbasis peternakan rakyat dengan skala usaha kecil, manajemen sederhana, perkembang biakannya dilakukan secara kawin alam dan in breeding, iii) lokasi tidak terkonsentrasi dan belum menerapkan sistem usaha agribisnis, iv) kurang optimalnya kelembagaan kelompok peternak berakibat para peternak kesulitan jika menghadapi masalah, hal ini berpengaruh terhadap informasi dan inovasi-inovasi baru yang dapat masuk.
Menjawab permasalahan di atas untuk meningkatkan produksi ternak sejatinya dimulai dari pengembangkan pembibitan ternak, perlu adanya kerja sama dan interaksi yang kuat antara pemerintah dan kelompok masyarakat. Salah satu langkah strategis untuk memenuhi kebutuhan bibit kerbau rawa adalah membentuk, membina dan mengembangkan pusat pembibitan desa (Village Breeding Centre), VBC ini mampu mengembangkan peternakan berkelanjutan.

Target luaran pelaksanaan Program Pengembangan Desa Mitra (PPDM) di Desa Sapala yaitu : berkembangnya kelembagaan pembibitan ternak pada peternakan rakyat, tercapainya perbaikan mutu genetik bibit memenuhi standar nasional, harga bibit yang bersaing, pengembangan ternak unggulan daerah, sebagai zona penyangga (buffer zone). 


\section{METODE PELAKSANAAN KEGIATAN}

1. Skema Pelaksanaan dan Pola Penyelesaian Masalah

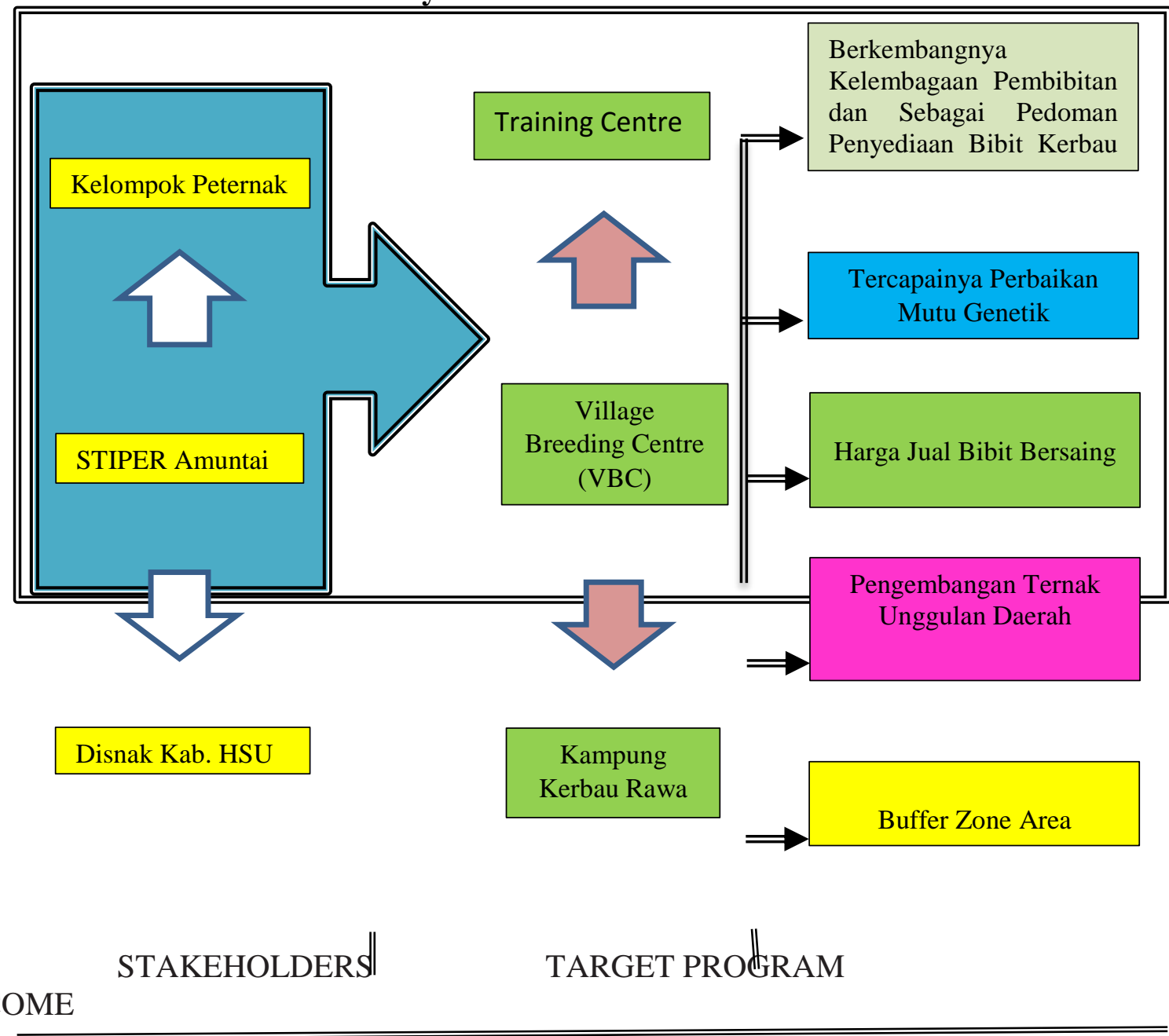

Gambar 1. Konsep pembentukan, target program, outcome dalam pembentukan Village Breeding Centre (VBC)

\section{Lokasi}

Lokasi pelaksanaan Village Breeding Centre (VBC) kerbau rawa di Desa Sapala. Lokasi sudah disesuaikan dengan RUTR (rencana umum tata ruang) dan RDTRD (rencana detail tata ruang daerah) guna mengetahui kesesuaian teknis lokasi yang ditetapkan. Pemilihan lokasi VBC juga berdasarkan pada potensi wilayah seperti: sumber hijauan pakan yang melimpah, pengalaman masyarakat beternak kerbau rawa, peluang pasar yang terbuka, dan adanya kelompok peternak yang sudah berjalan, serta pertimbangan minat peternak yang sangat mendukung. 


\section{Kelompok Peternak}

Desa Sapala mempunyai 6 kelompok peternak, seperti pada tabel berikut : Tabel 1. Kelompok Peternak di Desa Sapala, Kecamatan Peminggir, Kab. HSU

\begin{tabular}{ccclcc}
\hline Kecamatan & Desa & $\begin{array}{c}\text { Jenis } \\
\text { Usaha }\end{array}$ & Nama Kelompok & Anggota & $\begin{array}{c}\text { Populasi } \\
\text { Kerbau }\end{array}$ \\
\hline Paminggir & Sapala & Kerbau & Karya Baru & 20 & 325 \\
& & Rawa & Beruntung & 22 & 80 \\
& & Bersahaja & 20 & 287 \\
& & Karya Bersama & 20 & 312 \\
& & Harapan Bersama & 15 & 265 \\
& & Kerjasama & 19 & 119 \\
\hline & & & 116 & 1.388 \\
\hline
\end{tabular}

Sumber : Data Primer Yang Diolah, 2018

Jumlah anggota 116 orang dan aktif sejak tahun 2005, kelompok peternak akan diarahkan pada usaha pembibitan kerbau rawa yang akan dikembangkan untuk terbentuknya village breeding centre (VBC) atau memperkuat peternakan rakyat yang sudah ada. Anggota kelompok peternak ini merupakan penduduk lokal sehingga akan diberikan bimbingan teknis untuk pengembangan pembibitan.

Setiap anggota kelompok memiliki lahan dengan luas yang bervariasi, sehingga sangat tepat untuk pengembangan pembibitan. Dilaksanakan sosialisasi untuk meminta ketersediaan setiap anggota kelompok menjadi mitra dari kegiatan VBC. Selanjutnya ditetapkan kelompok peternak Karya
Baru, Karya Bersama, sebagai kelompok mitra VBC pada tahun I. Kelompok Beruntung, Harapan Bersama, dilanjutkan pada tahun II, dan pada tahun III akan dilanjutnya pada kelompok peternak Bersahaja, dan Kerjasama.

4. Village Breeding Centre (VBC) Kerbau Rawa

Pendampingan VBC sesuai dengan langkah dalam proses produksi bibit kerbau berdasarkan Peraturan Menteri Pertanian No. 56/Permentan/OT.140/2006 tentang Pedoman Perbibitan Kerbau yang Baik (Good Breeding Practice) antara lain meliputi asfek : Pemeliharaan, Produksi, Seleksi Bibit, Perkawinan, Ternak Pengganti (replacement stock), Afkir (culling), 
Pencatatan (recording), Persilangan,

Sertifikasi, Kesehatan Hewan,

Pemasaran, Monev Program, dan

Pendampingan Bisnis (Business

Coaching).

\section{HASIL DAN PEMBAHASAN}

Berkembangnya

Kapasitas

\section{Kelompok Ternak}

Kelompok peternakan kerbau rawa di Desa Sapala sudah berjalan cukup baik, namun masih perlu pembinaan dari tim PPDM STIPER Amuntai untuk penguatan kelembagaan, sarana dan prasarana. Penguatan kelembagaan peternakan dan peningkatan kualitas sumberdaya manusia peternak yang telah dilakukan melaui kegiatan penyuluhan, pendampingan, temu usaha, dan pelatihan-pelatihan.

Sudah tampak terjadi penguatan kapasitas pada kelompok peternak di desa Sapala yaitu perubahan sikap, keterampilan dan pengetahuan dari peternak menjadi lebih inovatif, kreatif. James, A (1989) pemberdayaan masyarakat adalah proses pembangunan dimana masyarakat berinisiatif untuk memulai proses kegiatan sosial memperbaiki situasi dan kondisi diri sendiri. Lebih lanjut Suhaimi, A (2016) menjelaskan bahwa pemberdayaan masyarakat hanya bisa terjadi apabila warganya ikut berpartisipasi.

Satu sisi, masyarakat beranggapan tradisi beternak yang mereka anggap lebih baik dan tetap harus dijaga sebagai sebuah potensi kearifan lokal dalam usaha peternakan. Pada sisi lain adanya keterbatasan tenaga penyuluh dari pemerintah, dan lokasi Desa Sapala yang hanya bisa ditempuh jalan sungai dengan kapal klotok ataupun speed boat dari kecamatan Danang Panggang.

Desa Sapala mempunyai 6 kelompok peternak, seperti pada tabel berikut

Tabel 2. Kelompok Peternak di Desa Sapalah, Kecamatan Peminggir, Kab. HSU

\begin{tabular}{ccclcc}
\hline Kecamatan & Desa & Jenis Usaha & Nama Kelompok & Anggota & $\begin{array}{c}\text { Populasi } \\
\text { Kerbau }\end{array}$ \\
\hline Paminggir & Sapala & Kerbau Rawa & Karya Baru & 20 & 325 \\
& & & Beruntung & 22 & 80 \\
& & & Bersahaja & 20 & 287 \\
& & & Karya Bersama & 20 & 312 \\
& & & Harapan Bersama & 15 & 265 \\
& & Kerjasama & 19 & 119 \\
\hline & & & 116 & 1.388
\end{tabular}


Jumlah anggota 116 orang dan aktif sejak tahun 2005, kelompok peternak sudah diarahkan pada usaha pembibitan kerbau rawa yang dikembangkan untuk terbentuknya village breeding centre (VBC) atau memperkuat peternakan rakyat yang sudah ada. Anggota kelompok peternak ini merupakan penduduk lokal sehingga akan diberikan bimbingan teknis untuk pengembangan pembibitan.

Tabel 3. Kapasitas Kelompok Ternak

\begin{tabular}{lll}
\hline \multicolumn{1}{c}{ Kelompok Ternak } & \multicolumn{1}{c}{ Program Pengembangan Desa Mitra (PPDM) } \\
\cline { 2 - 3 } & \multicolumn{1}{c}{ Sebelum } & \multicolumn{1}{c}{ Setelah } \\
\hline Struktur Organisasi & Sudah ada & Sudah Ada \\
\hline Visi dan Misi & Belum ada & Sudah Ada \\
\hline Potensi Kelompok Ternak : & & \\
\hline - Jumlah Ternak & 325 ekor & 370 ekor \\
- Luas Lahan Penggembalaan & Tidak Terdata & 20 Ha \\
- Jumlah Kandang & Tidak Terdata & 20 \\
- Aset Finansial & Tidak Terdata & 370 Ekor \\
\hline Jadwal Kegiatan Kelompok & Belum Ada & Ada \\
\hline Penerapan Fungsi Manajemen : & & \\
\hline - Perencanaan & Belum Ada & Sudah Berjalan \\
- Pengorganisasian & Belum Ada & Sudah Berjalan \\
- Penggerakan & Belum Ada & Sudah Berjalan \\
- Pengawasan & Belum Ada & Sudah Berjalan \\
\hline \multicolumn{1}{c}{ Kelompok Ternak } & Program Pengembangan & Desa Mitra (PPDM) \\
\cline { 2 - 3 } Karya Bersama & \multicolumn{1}{c}{ Sebelum } & \multicolumn{1}{c}{ Setelah } \\
\hline Struktur Organisasi & Sudah ada & Sudah Ada \\
\hline Visi dan Misi & Belum ada & Sudah Ada \\
\hline Potensi Kelompok Ternak : & & \\
\hline - Jumlah Ternak & 265 ekor & 301 ekor \\
- Luas Lahan Penggembalaan & Tidak Terdata & 20 Ha \\
- Jumlah Kandang & Tidak Terdata & 15 \\
- Aset Finansial & Tidak Terdata & 301 ekor \\
\hline Jadwal Kegiatan Kelompok & Belum Ada & Ada \\
\hline Penerapan Fungsi Manajemen : & & Sudah Berjalan \\
\hline - Perencanaan & Belum Ada & Sudah Berjalan \\
- Pengorganisasian & Belum Ada & Sudah Berjalan \\
- Penggerakan & Belum Ada & \\
- Pengawasan & Belum Ada & \\
\hline
\end{tabular}

Tingginya nilai kepemilikan

kerbau rawa di daerah ini karena kerbau rawa sudah diusahakan secara turun temurun. Peternak pemula dengan jumlah penguasaan ternak kerbau rawa yang kurang dari 5 ekor, namun 
peternak pemula sudah mempunyai pengalaman memelihara dari keluarga sebelumnya. Berselang beberapa tahun jumlah ternak kerbau rawa semakin bertambah melalui kelahiran maupun penitipan ternak dari pihak lain untuk dipelihara dengan bagi hasil yang dispekati.
1. Tercapainya Perbaikan Mutu Genetik Bibit Memenuhi Standar Nasional

Pelaksanaan pendampingan

VBC sesuai dengan langkah dalam proses produksi bibit kerbau berdasarkan Peraturan Menteri

Pertanian No.

56/Permentan/OT.140/2006 tentang

Pedoman Perbibitan Kerbau yang

Baik (Good Breeding Practice).

Tabel 4. Pelaksanaan Pendampingan Village Breeding Centre

\begin{tabular}{|c|c|c|}
\hline \multirow{2}{*}{$\begin{array}{l}\text { Perbaikan Mutu } \\
\text { Genetik }\end{array}$} & \multicolumn{2}{|c|}{ Program Pengembangan Desa Mitra (PPDM) } \\
\hline & Sebelum & Setelah \\
\hline Pemeliharaan & $\begin{array}{l}\text { Padang } \\
\text { Penggembalaan }\end{array}$ & Padang Penggembalaan \\
\hline Produksi & Rumpun murni & Rumpun Persilangan \\
\hline Seleksi Bibit & $\begin{array}{l}\text { Berdasarkan } \\
\text { kebisaan, tidak ada } \\
\text { petunjuk acuan. }\end{array}$ & $\begin{array}{l}\text { Berdasarkan performan anak dan } \\
\text { individu calon bibit }\end{array}$ \\
\hline Perkawinan & $\begin{array}{l}\text { Alami dan } \\
\text { Inbreeding }\end{array}$ & $\begin{array}{l}\text { Pelaksanaan kawin alam dan IB } \\
\text { dilakukan pengaturan penggunaan } \\
\text { pejantan atau semen untuk menghindari } \\
\text { terjadinya perkawinan sedarah } \\
\text { (inbreeding) }\end{array}$ \\
\hline $\begin{array}{l}\text { Ternak Pengganti } \\
\text { (replacement stock) }\end{array}$ & Belum dilakukan & $\begin{array}{l}\text { Calon bibit betina dipilih } 25 \% \text { terbaik } \\
\text { untuk replacement, } 10 \% \text { untuk } \\
\text { pengembangan populasi kawasan, } 60 \% \\
\text { dijual ke luar kawasan sebagai bibit dan } \\
5 \% \text { dijual sebagai ternak afkir, calon } \\
\text { bibit jantan dipilih } 10 \% \text { terbaik pada } \\
\text { umur sapih dan bersama calon bibit } \\
\text { betina } 25 \% \text { terbaik untuk dimasukkan } \\
\text { dalam uji performan. }\end{array}$ \\
\hline Afkir (culling) & Belum dilakukan & $\begin{array}{l}\text { Bibit rumpun murni } 50 \% \text { kerbau bibit } \\
\text { jantan peringkat terendah saat seleksi } \\
\text { pertama (umur sapih terkoreksi) } \\
\text { dikeluarkan dengan dikastrasi dan } 40 \%\end{array}$ \\
\hline
\end{tabular}


Pencatatan

(recording)

Persilangan

Sertifikasi

Kesehatan Hewan

Pemasaran

Pendampingan

Monev Program, Pelaporan

Business Coaching) Belum dilakukan

Belum dilakukan dilakukan oleh Pemda dari Pemda di jual ke luar kawasan

Rumpun, silsilah, perkawinan (tanggal, pejantan, IB/kawin alam), kelahiran (tanggal, bobot lahir), penyapihan (tanggal, bobot badan), beranak kembali (tanggal, paritas), pakan (jenis, konsumsi), vaksinasi, pengobatan (tanggal, perlakuan/treatment), mutasi (pemasukan dan pengeluaran ternak).

Belum dilakukan Komposisi darah kerbau persilangan sebaiknya dijaga agar komposisi darah kerbau impor tidak lebih dari 50\%; prinsip-prinsip seleksi dan culling sama dengan pada rumpun murni.

Belum dilakukan Belum dilakukan

Petunjuk Teknis PPL - Petunjuk Teknis Dokter Hewan

- Pemberian bantuan vaksin, vitamin, dan obat-obatan dari Tim PPDM STIPER Amuntai

Lokal dan kabupaten Dikelola oleh kelompok ternak untuk dipasarkan ke pedagang besar

Kadang-kadang $\quad 1$ kali dalam sebulan selama 1 tahun

Tergantung program

Pengumpulan data : performan tubuh, performan produksi dan reproduksi, serta kesehatan bibit. dilakukan oleh STIPER Amuntai

Pendampingan aspek finansial meliputi perhitungan modal, serta perhitungan kelayakan dengan metode BEP, PP ,NPV, IRR, PI.

\section{Harga Bibit Yang Bersaing}

Tim PPDM STIPER Amuntai bekerjasama dengan Dinas Pertanian dan Peternakan Kabupaten Hulu Sungai Utara untuk memberikan perlindungan harga ternak berdasarkan (Peraturan Pemerintah
RI Nomor 6 Tahun 2013) tentang pemberdayaan peternak yaitu : a. penetapan harga dasar ternak bibit dan harga dasar ternak bukan bibit; dan b. pemberian kemudahan kepada peternak untuk menjual ternak bibit ke seluruh wilayah negara RI. c. 
harga dasar ternak bibit ditetapkan sesuai dengan nilai mutu genetik dan harga dasar.

\section{Pengembangan Ternak Unggulan}

\section{Daerah}

Tim PPDM STIPER Amuntai sering melakukan advokasi pada beberapa event daerah dalam rangka mempromosikan dan mengembangkan keunggulan komparatif dan keunggulan kompetitif komoditas lokal kerbau rawa sebagai destinasi pariwisata provinsi Kalimantan Selatan dan khususnya di Desa Sapala, Kecamatan Paminggir, Kabupaten Hulu Sungai Utara.

Seminar-seminar

untuk

pengarusutamaan

perencanaan

pembangunan yang partisipatif yaitu melibatkan peternak dan investor, sehingga terciptanya model pariwisata berbasis peternakan kerbau di lahan rawa yang unik dan menarik sebagai energi pariwisata. Sesuai pendapat Suryana (2007), di Kabupaten Hulu Sungai Utara
(HSU), pengembangan kerbau rawa selain sebagai penghasil daging, juga merupakan salah satu objek wisata, berupa perlombaan atau pacuan kerbau di rawa.

\section{Sebagai Kawasan Penyangga}

\section{(Buffer Zone)}

Tim PPDM STIPER dan Walhi Kalimantan Selatan memfasilitasi masyarakat Desa Sapala dalam memperjuangkan penetapan Hak Pengelolaan Hutan Desa di Hutan Produksi untuk lahan penggembalaan kerbau rawa yang sekaligus sebagai kawasan penyangga. Sesuai pendapat Setyawati (2002) dan Bismark (2002), pengelolaan daerah penyangga adalah perpaduan keserasian pengelolaan lahan hutan dan pertanian sesuai dengan kondisi fisik kawasan untuk mendapatkan hasil optimal guna menunjang sistem perekonomian masyarakat lokal. Untuk itu daerah penyangga dibedakan penataanya atas wilayah wilayah (zonasi) yaitu jalur hijau, jalur interaksi dan jalur budidaya. 


\section{PETA LOKASI PROGRAM PENGEMBANGAN DESA MITRA}

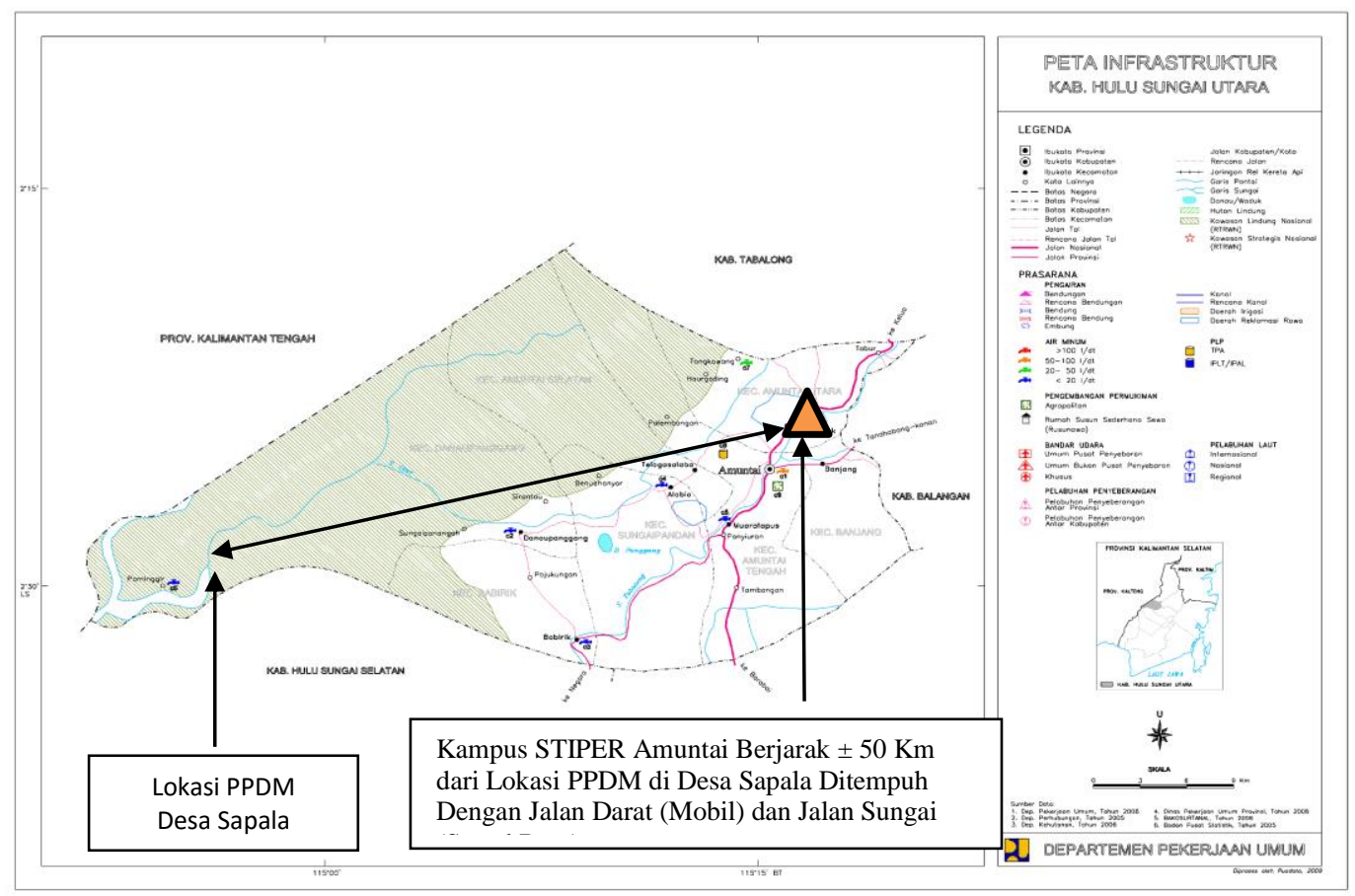

Gambar 1. Peta Lokasi PPDM, Desa Sapala Kec. Paminggir, Kab HSU, Kal-Sel

\section{KESIMPULAN}

1. Zona agroekologis lahan rawa lebak di desa Sapala sangat menguntungkan untuk budidaya kerbau rawa, menduduki peran strategis sebagian besar masyarakat, tidak hanya sebagai penghasil daging, sumber pendapatan, daya tarik pariwisata.

2. Model Village Breeding Centre yang dirancang dan diimplementasikan dapat memberikan manfaat penguatan kapasitas kepada kelompok ternak Karya Baru dan Kelompok ternak Karya Bersama untuk menjadikan desa Sapala sebagai pelopor Sentra produksi bibit kerbau rawa.

\section{DAFTAR PUSTAKA}

Bismark, M, 2002. Integrasi Kepentingan Konservasi dan Kebutuhan Sumber Penghasilan Masyarakat Dalam Pengelolaan Kawasan Konservasi. Prosiding Hasil - Hasil Litbang Rehabilitasi dan Konservasi Sumberdaya Hutan. P3HKA, Bogor.

BPS Kalimantan Selatan, 2011. Kalimantan Selatan Dalam Angka Tahun 2011.

BPS Kalimantan Selatan, 2014. Kalimantan Selatan Dalam Angka Tahun 2014.

Direktorat Jenderal Peternakan, 2010. Direktorat Jenderal Peternakan dan Kesehatan Hewan. Tingkat konsumsi Daging Menurut Provinsi dan Jenis Ternak 20062010. 
James A. Christenson \& Jerry W. Robinson, Jr Ames. 1989. Community development in perspective. Iowa State University Press.

Peraturan Menteri Pertanian No. 56/Permentan/OT.140/2006 tentang Pedoman Perbibitan Kerbau yang Baik (Good Breeding Practice).

Peraturan Pemerintah RI Nomor 6 Tahun 2013 tentang pemberdayaan peternak.

Rohaeni, E.S., A. Darmawan, R. Qomariah, A. Hamdan Dan A.Subhan. 2005. Inventarisasi dan Karakterisasi Kerbau Rawa sebagai Plasma Nutfah. Laporan Hasil Pengkajian. Balai Pengkajian Teknologi Pertanian (BPTP) Kalimantan Selatan. Banjarbaru.

Setyawati .T, 2002. Prioritas Konservasi Keanekaragaman Tumbuhan di Indonesia. Buletin Penelitian dan Pengembangan Kehutanan, 3.(2) : 131- 144

Siregar, A. 2004. Pengembangan ternak kerbau melakui aplikasi Inseminasi Buatan (IB) di Indonesia. Makalah disampaikan pada Seminar dan Lokakarya Nasional Peningkatan Populasi dan Produktivitas Ternak Kerbau di Indonesia, Banjarmasin, 7-8 Desember 2004.

SK Menteri Pertanian RI No. 2844/Kpts/LB.430/B/2012 tentang penetapan rumpun Kerbau Kalimantan Selatan (kerbau kalang).

Suhaimi, A (2016). Pengembangan dan Pemberdayaan Masyarakat. Konsep Pembangunan Partisipatif Wilayah Pinggiran dan Desa. Penerbit Deepublish, Yogyakarta.

Suhaimi, A., Zarmiyeni, A. Saihani, R.V. Royensyah, 2016. Kajian Potensi dan Strategi Pengembangan Kerbau Rawa Dalam Menyokong Ketahanan Pangan Berbasis Sumberdaya Lokal. Laporan Penelitian Unggulan Perguruan Tinggi. Sekolah Tinggi Ilmu Pertanian (STIPER) Amuntai. Kalimantan Selatan.

Suryana, 2007. Usaha Pengembangan Kerbau Rawa Di Kalimantan Selatan. Balai Pengkajian Teknologi Pertanian Kalimantan Selatan, Banjarbaru 